\title{
Effect of Use Fresh Macro Algae (Seaweed) Ulva fasciata and Enteromorpha flaxusa With or Without Artificial Feed on Growth Performance and Feed Utilization of Rabbitfish (Siganus rivulatus) fry
}

\section{Mohamed FA Abdel-Aziz* and Mohammed A Ragab}

Fish Rearing Lab, Aquaculture Division, National Institute of Oceanography and Fisheries (NIOF), Egypt

\begin{abstract}
This study a low-cost aquaculture diet with fresh seaweed was tested with the herbivorous rabbitfish (Siganus rivulatus) fry. Two fresh seaweed was genera, Ulva and Enteromorpha (belong to family Ulvaceae) were used to replace the artificial feed by 0,50 and 100 percent regardless the protein percentage. Initial average weight of fry was $0.18 \mathrm{~g}$. This trial consisted of sixth treatments, the first treatment (T1) fish fed on artificial feed only, the (T2) fish fed of half feeding rate on artificial feed and other fresh Ulva, the (T3) fish fed of half feeding rate on artificial feed and other fresh Enteromorph, the (T4) fish fed on fresh Ulva only, the (T5) fish fed on fresh Enteromorpha only and the (T6) fish fed of half feeding rate on fresh Ulva and other fresh Enteromorph. Feeding rat was $7 \%$ of biomass and this trial continued for 70 days. There were significant differences between the treatments in all the growth performance parameters. The $T 3$ was the highest in final weight $\left(\mathrm{W}_{2}\right)$, total weight gain (TG), average daily gain (ADG), relative growth rate (RGR) and specific growth rate (SGR), followed by both the T2 and T1. And the best feed conversion ratio (FCR) was achieved with T3, T1 and T2 followed by T6 and T5 but the T4 had the worst FCR.
\end{abstract}

Keywords: Rabbitfish; Macro algae; Feeding rate; Growth performance; Feed utilization

\section{Introduction}

Marbled spinefoot rabbitfish Siganus rivulatus is a potential for warm water marine aquaculture diversification [1,2]. Rabbitfishes belong to the genus Siganus of the family siganidae [3]. Siganids are herbivorous marine and brackish water fishes that are found throughout the indo west pacific [4], and the more common species are the objects of traditional subsistence and commercial fisheries throughout this region. There has been interest in the culture of these fishes in ponds or cages in several areas [5].

Being herbivorous, the siganus species need a big quantity of algae feed to assure their biological activities. The stomach of these fishes is an acid medium able to digest marine plants before entering in the digestive tract for complete digestion and thus excreting feces. In addition to algae feed, they can feed accidentally on some nondigestible substances such as mollusk shells and other invertebrates attached to algae [6,7]. Egypt production of rabbitfish was about 1363 ton in 2014, Mediterranean Sea took part in 822 ton production, Red Sea (466 ton) and lakes (75 ton) according to GAFRD [8].

Marine macro algae, or seaweed, are plantlike organisms that generally live attached to rock or other hard substrata in coastal areas. They belong to three different groups, empirically distinguished since the mid-nineteenth century on the basis of thallus color: - red algae (phylum Rhodophyta), brown algae (phylum Heterokontophyta (also known as the Ochrophyta), class Phaeophyceae), and green algae (phylum Chlorophyta, classes Bryopsidophyceae, Chlorophyceae, Dasycladophyceae, Prasinophyceae, and Ulvophyceae). There are about 8,000 species of macro algae (seaweeds) along the world's coast live and they may extend as deep as $270 \mathrm{~m}$ [9]. A total of 25 species of green sea weeds, 90 species of brown and 350 species of red seaweeds are found in the world sea area that are commercially important because of their protein, amino acids and mineral contents [10]. The protein content of seaweed differs according to species and seasonal period. Generally, the protein fraction of brown seaweeds is low (3\% to $5 \%$ of the dry weight) compared with that of the green or red seaweed (10\% to $47 \%$ of the dry weight). The content of crude protein, crud lipid, ash and fiber in green meals from $7 \%$ to $29 \%, 0.5 \%$ to $4 \%, 13 \%$ to $36 \%$ and from $3 \%$ to $6 \%$ respectively $[11,12]$.

Seaweeds are rarely promoted for the nutritional value of their proteins [13]. Considering the importance of seaweeds, it can be said that, sea weeds can play a vital role in various aspects compared to other aquatic resources. Much attention should be given on seaweed to compensate the food problem to some extent and fulfill the deficiency of nutrition for erecting the economy of several countries [14].

All green seaweed belong to the classes Ulvophyceae, Bryopsidophyceae, and Dasycladophyceae, which include approximately 1,500 species currently referred to eight orders [15]. The genus Ulva (Phylum: Chlorophyta, Class: Ulvophyceae, Order: Ulvales, Family: Ulvaceae) was first identified by Linnaeus in 1753 [16]. Since then many taxonomists and phycologists have been involved in the identification of Ulva species which are notoriously difficult to classify due to the morphological plasticity expressed by many members as well as the few reliable characters available for differentiating taxa [17].

Ulva is a good source of protein, pigments, minerals and vitamins, and is especially rich in vitamin C $[18,19]$ and, in recent years, Ulva species have become important macro algae, which have been investigated as a dietary ingredient for a wide range of fish species.

*Corresponding author: Mohamed FAAbdel-Aziz, Fish Rearing Lab, Aquaculture Division, National Institute of Oceanography and Fisheries (NIOF), Egypt, Tel: 0227921341; E-mail: m_fathy8789@yahoo.com

Received April 06, 2017; Accepted May 22, 2017; Published May 24, 2017

Citation: Abdel-Aziz MFA, Ragab MA (2017) Effect of Use Fresh Macro Algae (Seaweed) Ulva fasciata and Enteromorpha flaxusa With or Without Artificial Feed on Growth Performance and Feed Utilization of Rabbitfish (Siganus rivulatus) fry. $J$ Aquac Res Development 8: 482. doi: 10.4172/2155-9546.1000482

Copyright: () 2017 Abdel-Aziz MFA, et al. This is an open-access article distributed under the terms of the Creative Commons Attribution License, which permits unrestricted use, distribution, and reproduction in any medium, provided the original author and source are credited. 
Citation: Abdel-Aziz MFA, Ragab MA (2017) Effect of Use Fresh Macro Algae (Seaweed) Ulva fasciata and Enteromorpha flaxusa With or Without Artificial Feed on Growth Performance and Feed Utilization of Rabbitfish (Siganus rivulatus) fry. J Aquac Res Development 8: 482. doi: 10.4172/2155-9546.1000482

Page 2 of 8

Enteromorpha (Phylum: Chlorophyta, Class: Ulvophyceae, Order: Ulvales, Family: Ulvaceae) have also been used as a source of bioactive compounds similar to those which cause an inhibitory effect against the bacterium Xanthomonas oryzae, which causes leaf blight disease in paddy crops [20]. People in the Philippines and Japan also use Enteromorpha spp. as food [21,22].

The study aimed to evaluate the effect of use fresh macro algae including feeding rate with artificial feed on growth performance, feed efficiency and feed cost of rabbitfish fry. Whereas the most of the cultured marine fish are carnivorous species, and seldom are herbivorous or omnivorous species, and the higher prices and uncertainty of availability of fishmeal (FM) is limiting the development of mariculture industry, especially the culture of carnivorous fish. So FAO (food and agriculture organization) quite canonizes the culture of herbivorous or omnivorous species [23]. From this point, the present study presented some information for the development of low-cost diets with fresh macro algae as dietary ingredient for the culture of marine fish such as herbivorous rabbitfish fry.

\section{Materials and Methods}

The present study was conducted using the research facilities of Shakshouk Fish Research Station, Fayoum Governorate, National Institute of Oceanography and Fisheries (NIOF), Egypt. Rabbitfish (Siganus rivulatus) fry were obtained from (Mediterranean Sea) National Institute of Oceanography and Fisheries (NIOF), Alexandria Governorate, Egypt, initial average weight for this fry was $0.18 \pm 0.012$ $\mathrm{g}$ (SE standard error) and initial average length was $2.76 \pm 0.057 \mathrm{~cm}$.

\section{Fish acclimatization and diet preparation}

Fry were acclimatized to be adapted to water salinity of Lake Qaroun 33 part per thousand (ppt) for one week. An artificial diet was formulated by hand, the diet formulated to be almost containing $36 \%$ crude protein (Table 1) and two genuses of macro algae belong to family Ulvaceae, the first genus Ulva (Ulva fasciata) was collected from Mediterranean sea, Alexandria Governorate, Egypt and the second genus Enteromorpha (Enteromorpha flaxusa) was collected from Qaroun lake, Fayoum Governorate, Egypt. After operation collection,

\begin{tabular}{|c|c|}
\hline Ingredients & $(g / 100 \mathrm{~g})$ \\
\hline Fish meal $(72 \% \mathrm{CP})$ & 22 \\
\hline Extruded full fat Soybean meal $(37 \% \mathrm{CP})$ & 43 \\
\hline Wheat bran fine & 28 \\
\hline Fish oil & 4 \\
\hline Super yeast & 1 \\
\hline Starch & 1.7 \\
\hline Vit. \& Min. \& premix & 0.3 \\
\hline Total & 100 \\
\hline \multicolumn{2}{|c|}{ Chemical analysis $\%$ on dry matter basis } \\
\hline Moisture (M) & 6.94 \\
\hline Dry matter (DM) & 93.06 \\
\hline Crude protein $(\mathrm{CP})$ & 36.44 \\
\hline Ether extract (EE) & 13.78 \\
\hline Crude fiber (CF) & 3.10 \\
\hline Nitrogen free extract (NFE) & 39.02 \\
\hline Ash & 7.66 \\
\hline Gross energy (GE, Kcal/g)* & 5.09 \\
\hline $\begin{array}{l}\text { Chemical analysis was determined acc } \\
\text { calculated by difference. } \\
{ }^{*} \text { Calculated according to NRC [27]. }\end{array}$ & AOAC [26] and NFE was \\
\hline
\end{tabular}

\begin{tabular}{|l|l|l|}
\hline Items & $\begin{array}{l}\text { Ulva (Ulva } \\
\text { fasciata) }\end{array}$ & $\begin{array}{l}\text { Enteromorpha (Enteromorpha } \\
\text { flaxusa) }\end{array}$ \\
\hline Moisture (M) & 76.10 & 78.60 \\
\hline Dry matter (DM) & 23.90 & 21.40 \\
\hline Crude protein (CP) & 27 & 25.03 \\
\hline Ether extract (EE) & 0.57 & 1.74 \\
\hline Crude fiber (CF) & 9.81 & 4.61 \\
\hline $\begin{array}{l}\text { Nitrogen free extract } \\
\text { (NFE) }\end{array}$ & 42.56 & 38.43 \\
\hline \begin{tabular}{l} 
Ash \\
\hline $\begin{array}{l}\text { Gross energy (GE, } \\
\text { Kcal/g) }\end{array}$
\end{tabular} & 20.06 & 30.19 \\
\hline $\begin{array}{l}\text { Chemical analysis was } \\
\text { calculated by difference } \\
{ }^{*} \text { Calculated according to NRC [27]. }\end{array}$ & 3.73 \\
\hline
\end{tabular}

Table 2: A proximate chemical analysis $\%$ on dry matter basis of the fresh macro algae (seaweed).

the seaweed were kept in colder and used freshly in fish feeding (Table 2). Feed was offered by hand.

The trial began at 25/7/2015 and ended 3/10/2015, (70 days). An average initial weight $\left(\mathrm{W}_{1}\right)$ of fry was $0.18 \pm 0.012 \mathrm{~g}$ and initial average length $\left(L_{1}\right)$ was $2.76 \pm 0.05 \mathrm{~cm}$.

\section{Trial design and distribution of fish in ponds}

The indoor ponds laboratory were made of concrete, this trial consists of twelve concrete ponds. The dimensions of each pond were 1 $\mathrm{m}$ length $\times 1 \mathrm{~m}$ width $\times 1 \mathrm{~m}$ height and the water volume of each pond was $0.95 \mathrm{~m}^{3}$.

This trial consists of six treatments, the first treatment, fish fed on artificial feed only. The second treatment, fish were fed of half feeding rate on artificial feed and other fresh Ulva fasciata, the third treatment, fish were fed of half feeding rate on artificial feed and other fresh Enteromorpha flaxusa, the fourth treatment, fish fed of feeding rate on fresh Ulva fasciata only, the fifth treatment, fish fed on fresh Enteromorpha flaxusa only and sixth treatment fish fed of half feeding rate on fresh Ulva fasciata and other fresh Enteromorpha flaxusa. It did not take into consideration the percentage of protein diet, but was taking the variety feed. Feeding rate was $7 \%$ of fish body weight, 40 fish were stocked in each pond ( $\mathrm{n}=80$ fry for each treatment) and the feeding was twice daily. A random sample was taken every three week for change of feed quantity without any mortality for fish.

\section{The system of running water in experimental units}

The system contained on water pump, sand filter unit and two large tanks (10000 liter/tank) used to storage the water at a point between the water source (Lake Qaroun water) and experimental units. The water pump was raising the water from water source to the sand filter unit then to the large tanks and hence to experimental units.

\section{The system of aeration in experimental units.}

The system contained on Blower connected to a network of plastic pipes this pipes transport the air to each experimental unit, the air was controlled by tap of each pond or tank and the air diffusers was used to distribute of air in all experimental unit trends.

\section{Water quality}

Some water quality parameters were measured of each treatment, temperature, $\mathrm{pH}$ and salinity were measured daily at $1 \mathrm{pm}$ by centigrade thermometer, Orion digital $\mathrm{pH}$ meter model 201 and Refractometer (VITAL Sine SR-6, China) respectively. Dissolved oxygen (DO) was 
Citation: Abdel-Aziz MFA, Ragab MA (2017) Effect of Use Fresh Macro Algae (Seaweed) Ulva fasciata and Enteromorpha flaxusa With or Without Artificial Feed on Growth Performance and Feed Utilization of Rabbitfish (Siganus rivulatus) fry. J Aquac Res Development 8: 482. doi: $10.4172 / 2155-9546.1000482$

Page 3 of 8

\begin{tabular}{|c|c|c|c|c|c|c|}
\hline \multirow{3}{*}{ Items } & \multicolumn{6}{|c|}{ Treatments } \\
\hline & T1 & T2 & T3 & T4 & T5 & T6 \\
\hline & Artificial Feed Only & $\begin{array}{l}\text { Artificial feed } \\
\text { with Ulva }\end{array}$ & $\begin{array}{l}\text { Artificial feed with } \\
\text { Enteromorpha }\end{array}$ & Ulva Only & Enteromorpha Only & $\begin{array}{c}\text { Ulva with } \\
\text { Enteromorpha }\end{array}$ \\
\hline Temperature $\left({ }^{\circ} \mathrm{C}\right)$ & $28.502 \pm 0.159$ & $28.369 \pm 0.174$ & $28.466 \pm 0.162$ & $28.488 \pm 0.163$ & $28.487 \pm 0.164$ & $28.341 \pm 0.179$ \\
\hline $\mathrm{pH}$ & $8.418 \pm 0.079$ & $8.447 \pm 0.0746$ & $8.436 \pm 0.0782$ & $8.478 \pm 0.0497$ & $8.455 \pm 0.068$ & $8.523 \pm 0.039$ \\
\hline Salinity (\%o) & $32.772 \pm 0.401$ & $32.710 \pm 0.421$ & $32.622 \pm 0.443$ & $32.791 \pm 0.685$ & $32.523 \pm 0.396$ & $32.635 \pm 0.415$ \\
\hline $\mathrm{DO}(\mathrm{mg} / \mathrm{L})$ & $7.300 \pm 0.129$ & $7.425 \pm 0.165$ & $7.100 \pm 0.208$ & $6.700 \pm 0.147$ & $7.400 \pm 0.168$ & $8.000 \pm 0.258$ \\
\hline Nitrite (mg/L) & $0.078 \pm 0.001$ & $0.107 \pm 0.003$ & $0.081 \pm 0.002$ & $0.082 \pm 0.002$ & $0.074 \pm 0.002$ & $0.066 \pm 0.001$ \\
\hline Nitrate (mg/L) & $0.210 \pm 0.002$ & $0.143 \pm 0.002$ & $0.116 \pm 0.007$ & $0.135 \pm 0.006$ & $0.154 \pm 0.004$ & $0.136 \pm 0.005$ \\
\hline Total ammonia (mg/L) & $0.418 \pm 0.008$ & $0.537 \pm 0.007$ & $0.362 \pm 0.004$ & $0.382 \pm 0.002$ & $0.741 \pm 0.008$ & $0.467 \pm 0.004$ \\
\hline
\end{tabular}

Table 3: Mean $( \pm \mathrm{SE})$ of water quality parameters.

\begin{tabular}{|c|c|c|c|c|c|c|c|}
\hline \multirow{3}{*}{ Items } & \multicolumn{6}{|l|}{ Treatments } & \multirow{3}{*}{ SED* } \\
\hline & \multirow{2}{*}{\begin{tabular}{|l|} 
T1 \\
Artificial \\
Feed Only
\end{tabular}} & \multirow{2}{*}{\begin{tabular}{|l|} 
T2 \\
Artificial feed \\
with Ulva
\end{tabular}} & \multirow{2}{*}{$\begin{array}{l}\text { T3 } \\
\text { Artificial feed } \\
\text { with Enteromorpha }\end{array}$} & \multirow{2}{*}{\begin{tabular}{|l|} 
T4 \\
Ulva \\
Only
\end{tabular}} & \multirow{2}{*}{$\begin{array}{l}\text { T5 } \\
\text { Enteromorpha } \\
\text { Only }\end{array}$} & T6 & \\
\hline & & & & & & $\begin{array}{l}\text { Ulva with } \\
\text { Enteromorpha }\end{array}$ & \\
\hline Initial weight $\left(\mathrm{w}_{1}\right),(\mathrm{g})$ & 0.18 & 0.18 & 0.18 & 0.18 & 0.18 & 0.18 & - \\
\hline Final length $\left(\mathrm{L}_{2}\right),(\mathrm{cm})$ & $6.20^{\mathrm{a}}$ & $6.26^{\mathrm{a}}$ & $6.40^{\mathrm{a}}$ & $3.83^{c}$ & $3.93^{c}$ & $4.21^{\mathrm{b}}$ & 0.090 \\
\hline Final weight $\left(\mathrm{W}_{2}\right),(\mathrm{g})$ & $2.49^{b}$ & $2.95^{b}$ & $3.41^{\mathrm{a}}$ & $0.73^{d}$ & $0.67^{d}$ & $0.92^{c}$ & 0.070 \\
\hline Total weight gain $(\mathrm{TG}, \mathrm{g})$ & $2.31^{b}$ & $2.41^{b}$ & $3.23^{a}$ & $0.55^{d}$ & $0.49^{d}$ & $0.73^{c}$ & 0.070 \\
\hline Average daily gain (ADG), g/day) & $0.0330^{\mathrm{b}}$ & $0.0340^{\mathrm{b}}$ & $0.0460^{a}$ & $0.0075^{c}$ & $0.0070^{\circ}$ & $0.0100^{\circ}$ & 0.001 \\
\hline Relative growth rate (RGR), (\%) & $1283.30^{\mathrm{b}}$ & $1338.80^{b}$ & $1794.40^{\mathrm{a}}$ & $315.55^{c d}$ & $272.2^{d}$ & $408.33^{c}$ & 41.950 \\
\hline $\begin{array}{l}\text { Specific growth rate (SGR/day, } \\
\%)\end{array}$ & $3.75^{b}$ & $3.80^{b}$ & $4.20^{a}$ & $1.99^{d}$ & $1.87^{d}$ & $2.31^{c}$ & 0.118 \\
\hline Survival rate $(\mathrm{SR}, \%)$ & $75^{a}$ & $65^{\mathrm{ab}}$ & $55^{b}$ & $25^{c}$ & $28.75^{c}$ & $26.20^{c}$ & 5.460 \\
\hline
\end{tabular}

Table 4: Effect of use fresh macro algae with or without artificial feed on growth performance of rabbitfish (Siganus rivulatus) fry.

measured every week by oxygen meter (Cole Parmer model 5946). Nitrite, nitrate, total ammonia were measured every two week by the chemical methods according to $[24,25]$

\section{Measurements of growth performance and some of the internal organs}

Total weight gain (TG), average daily gain (ADG), Relative growth rate (RGR), specific growth rate (SGR) and survival rate (SR).

These parameters were calculated according the following equations:

$$
\begin{aligned}
& T G, g=\text { Final Weight }\left(W_{2}\right)-\text { Initial Weight }\left(W_{1}\right) \\
& A D G, g / \text { day }=\text { Average Weight Gain, } g / \text { Experimental Period, day } \\
& R G R, \%=\left[\left(W_{2}-W_{1}\right) / W_{1}\right] \times 100 \\
& S G R, \% / \text { day }=\left[\left(\ln W_{2}-\ln W_{1}\right) / t\right] \times 100
\end{aligned}
$$

whereas $\ln$ : is the natural log. and t: is the time in days,

$S R \%=($ Number of fish at end $/$ Number of fish at start $) \times 100$

\section{Measurements of feed utilization efficiency}

Feed intake g/fish (FI), feed conversion ratio (FCR), feed conversion efficiency (FCE), protein efficiency ratio (PER), protein productive value $(\mathrm{PPV})$, energy efficiency ratio (EER) and energy productive value (EPV).

These parameters were calculated according the following equations:

FI g/fish feed intake during the trial period/ the final number of fish for this trial
$F C R=$ Feed Intake, $g /$ Weight Gain, $g$

$F C E \%=($ Weight Gain, $g /$ Feed Intake, $g) \times 100$

PER $=$ Weight Gain, $g /$ Protein Intake, $g$

$P P V \%=($ Retained Protein, $g /$ Protein Intake, $g) \times 100$

EER $=$ Weight Gain, $g /$ Energy Intake, Kcal

$E P V \%=($ Retained Energy, Kcal / Energy Intake, Kcal $) \times 100$

\section{Chemical analysis of feeds and whole body fish}

The conversional chemical analysis of diet and whole body fish samples were carried out as described by AOAC [26] and Gross energy (GE) was estimated for formulated diets the factors $5.64 \mathrm{Kcal} / \mathrm{g}, 9.44$ $\mathrm{Kcal} / \mathrm{g}$ and $4.11 \mathrm{Kcal} / \mathrm{g}$ for $\mathrm{CP}, \mathrm{EE}$ and carbohydrates respectively were used [27], for fish $5.5 \mathrm{Kcal} / \mathrm{g}$ and $9.5 \mathrm{Kcal} / \mathrm{g}$ for protein and fat respectively [28].

\section{Statistical analysis}

The analysis of variance and LSD of Duncan Waller were used to compare treatment means. Data were analysed using stratigraphic package software [29] SPSS Inc. Released 2007. SPSS for Windows, Version 16.0. Level of significant was 0.05 .

\section{Results and Discussion}

\section{Water quality}

Some water quality parameters recorded in this trial were shown in Table 3 . The averages of water temperature, water $\mathrm{pH}$, water salinity, dissolved oxygen (DO), and nitrite, nitrate and total ammonia values in 
Citation: Abdel-Aziz MFA, Ragab MA (2017) Effect of Use Fresh Macro Algae (Seaweed) Ulva fasciata and Enteromorpha flaxusa With or Without Artificial Feed on Growth Performance and Feed Utilization of Rabbitfish (Siganus rivulatus) fry. J Aquac Res Development 8: 482. doi: 10.4172/2155-9546.1000482

all treatments were within the acceptable limits for rabbitfish (Siganus rivulatus) fry as reported by [2,30-37].

\section{Growth performance}

As shown in Table 4, there were significant differences between the treatments in all the growth performance parameters. The differences between the T1 (fry fed at artificial feed only), the T2 (fry fed at artificial feed with fresh Ulva) and the T3 (fry fed at artificial feed with fresh Enteromorpha) in final length $\left(\mathrm{L}_{2}\right)$ were not significant followed by the T6 (fry fed at fresh Ulva and fresh Enteromorpha). While the lowest $\mathrm{L}_{2}$ were obtained by T4 (fry fed at fresh Ulva only) and T5 (fry fed at fresh Enteromorpha only). The T3 was the highest in $\mathrm{W}_{2}$, TG, ADG, RGR and SGR. Followed by both the T2 and T1.

The T6 was the lower in these parameters than both the T2 and $\mathrm{T} 1$. But both the T4 and T5 were the lowest in all treatments in these parameters. The highest Survival rate (SR) was achieved with the T1 followed by the $\mathrm{T} 2$ and the T3. While insignificant differences between T4, T5 and T6.

From these results, it can be observed that, the total replacement of artificial feed with fresh macro algae had negative effect on growth performance of rabbitfish fry, however, use of the macro algae as half of the feeding rate with artificial feed had positive effect on growth performance of rabbitfish fry and reduce of the feed cost. The positive effects of macro algae on growth performance may be due to the algae are a strongly appreciated source of protein, essential amino acids [38] and vitamins [39].

As well as the positive effect of the used additive algae decrease the cholesterol and fat level and improved lipid metabolism in fish too [40]. And, Seaweeds cannot be considered as a main source of energy but they have nutritional value regarding vitamin, protein and mineral contents [41]. According to Chapman and Chapman [42], 100 g seaweed provides more than the daily requirement of Vitamin A, $\mathrm{B} 1$ and B12 and two thirds of Vitamin C. Also seaweeds are natural sources of hydrosoluble and liposoluble vitamins, such as thiamine and riboflavin, $b$-carotene and tocopherols, as well as of long-chain polyunsaturated essential fatty acids from the omega-3 ( $\omega-3)$ (family such as eicosapentaenoic acid [43]. Moreover, Some dietary macroalge meals are improved the growth, lipid metabolism, physiological activity, stress response, disease resistance and carcass quality of various fish species [44-46]. So gut weed can be used as a direct feed or as ingredient in diets for herbivorous fish according to Teimouri et al. [47].

Over and above, rabbitfish are herbivorous fish and mainly graze on seaweeds. However, they can also feed on formulated feed or trash fishes when seaweeds are absent [48].

Due to seasonal availability of seaweeds used for feed, it is necessary to develop a formulated feed in order to promote the development of an intensive aquaculture industry for rabbitfish. Studies of stomach contents and food preference revealed that rabbitfish feed on fresh green or red algae or benthic marine plants. Studies revealed that among the many different algal species, Gracilaria is the preferred species of food [49].

As well as most herbivorous fishes prefer fleshy seaweeds over calcareous coralline and encrusting seaweeds [50].

In view of the economic side, the fishmeal and fish oil remain the main protein and lipid sources of feed for marine fish, and the development and application of formulated feed are restricted by the high cost of these ingredients. Therefore, efforts should focus on producing commercial feed for rabbitfish at low cost and high efficiency [51]. Such as the use of seaweeds in the development of low-cost, highly nutritive diets for animal nutrition, especially animal nutrition since sea vegetables are able to accelerate the growth of oysters, tilapia, salmon, trout, etc., all of great commercial interest [52,53]. As well as marine macro algae could be a potential low-cost source of protein for fish [54]. Moreover, the economic comparison of feed cost indicated that increasing level of fresh and dried gut weed in alternative feeding treatments, commercial feed used for fish growth was reduced leading to significantly reduction of feed cost. Compare to commercial feed, treatments [55].

Likewise, $\mathrm{Xu}$ et al. [51] reported that, the Gracilaria lemaneiformis GL is the preferred food for S. canaliculatus, it is logical to utilize Dried Gracilaria lemaneiformis DGL as a dietary ingredient for developing low-cost feeds for $S$. canaliculatus. Utilization of DGL can perhaps partially replace protein from fish meal in feeds and reduce fishmeal inclusion, and secondly, the high level of carbohydrates in GL can reduce the amount of supplemental starch in formulated feeds and minimize competition with human food sources. Furthermore, application of GL in feed can promote the coordinated development of aquaculture industries for GL and rabbitfish and simultaneously increase incomes of fisherman. Previous studies [56] investigating inclusion of other plant ingredients in the diets of $S$. canaliculatus showed different results, not influencing growth.

In the light of the results were shown in Table 4 it can be observed that, the (T3) fish fed at artificial feed with fresh Enteromorpha was better in growth performance than the (T2) fish fed at artificial feed with fresh Ulva, this may be due to the fresh Ulva contained the higher percentage of fiber than fresh Enteromorpha as shown in Table 2 this was supported by Leary and Lovell [57] high levels of fiber in the diets of many finfish species, have been shown to reduce growth. For tilapia, Anderson et al. [58] concluded that dietary fiber levels above 5\% reduce food utilization and digestibility and protein utilization were reduced with excess fiber levels in the diets. As well as Ortiz et al. [18] reported that $U$. lactuca contains about $60 \%$ fiber this might reduce its value in aqua feeds. Early studies of stomach contents and food preference revealed that among the many different algal species and vascular plants eaten, the presence of Enteromorpha was high and was the preferred species. This preference for Enteromorpha by siganids is not directly related to the calorific value of the algae but is related to the texture of its thallic which is crispy and thin $[59,60]$. Moreover, the results confirmed that, the replacement at $50 \%$ of artificial diet with fresh macro algal (Enteromorpha or Ulva) from rabbitfish fry feed led to an increase in the growth performance parameters compared with $100 \%$ artificial diet. But the total replacement of artificial feed with fresh macro algal (Enteromorpha or Ulva) led to a decrease in the growth performance parameters, because protein percentage of the artificial feed was high level $(35 \% \mathrm{CP})$ in addition to artificial feed contained on fish meal (FM) which is high protein content and balanced essential amino acids EAA profile. Fish meal FM is also an excellent source of essential fatty acids (EFA), digestible energy, minerals and vitamins and it is well known as being highly palatable and digestible to fish [56,61]. The T6 (fish fed at Ulva with Enteromorpha) was the better in the growth performance and survival rate than T5 or T4, this may be due to both the Ulva with Enteromorpha has more a balanced amino acid composition than Ulva alone or Enteromorpha alone, in addition to the varying and mixture between Ulva and Enteromorpha resulted in highly palatable and digestible to fish.

In general, these results are in agreement with Costa et al. [62] 
Citation: Abdel-Aziz MFA, Ragab MA (2017) Effect of Use Fresh Macro Algae (Seaweed) Ulva fasciata and Enteromorpha flaxusa With or Without Artificial Feed on Growth Performance and Feed Utilization of Rabbitfish (Siganus rivulatus) fry. J Aquac Res Development 8: 482. doi: $10.4172 / 2155-9546.1000482$

Page 5 of 8

\begin{tabular}{|c|c|c|c|c|c|c|c|}
\hline \multirow[b]{3}{*}{ Items } & \multicolumn{6}{|l|}{ Treatments } & \multirow[b]{3}{*}{ SED* } \\
\hline & \multirow{2}{*}{\begin{tabular}{|l|} 
T1 \\
Artificial \\
Feed Only
\end{tabular}} & \multirow{2}{*}{$\begin{array}{l}\text { T2 } \\
\text { Artificial } \\
\text { feed with Ulva }\end{array}$} & \multirow{2}{*}{\begin{tabular}{|l|} 
T3 \\
Artificial \\
feed \\
with Enteromorpha
\end{tabular}} & \multirow{2}{*}{\begin{tabular}{|l} 
T4 \\
Ulva \\
Only
\end{tabular}} & \multirow{2}{*}{$\begin{array}{l}\text { T5 } \\
\text { Enteromorpha } \\
\text { Only }\end{array}$} & \multirow{2}{*}{\begin{tabular}{|l} 
T6 \\
Ulva with \\
Enteromorpha
\end{tabular}} & \\
\hline & & & & & & & \\
\hline Feed intake (FI), g/ fish & $3.54^{f}$ & $4.05^{e}$ & $4.70^{c}$ & $6.1^{\mathrm{a}}$ & $4.34^{d}$ & $5.04^{b}$ & 0.083 \\
\hline Feed conversion ratio (FCR) & $1.53^{c}$ & $1.68^{c}$ & $1.45^{c}$ & $11.22^{\mathrm{a}}$ & $8.85^{b}$ & $7.74^{b}$ & 0.752 \\
\hline $\begin{array}{l}\text { Feed conversion efficiency (FCE, } \\
\%)\end{array}$ & $65.25^{\mathrm{b}}$ & $59.50^{c}$ & $68.72^{\mathrm{a}}$ & $9.01^{\mathrm{e}}$ & $11.29^{e}$ & $14.55^{d}$ & 1.260 \\
\hline \multicolumn{8}{|l|}{ Protein utilization } \\
\hline Protein efficiency ratio (PER) & $1.79^{c}$ & $1.87^{b}$ & $2.23^{\mathrm{a}}$ & $0.33^{f}$ & $0.46^{e}$ & $0.56^{d}$ & 0.0116 \\
\hline Protein productive value (PPV, \%) & $86.32^{c}$ & $97.29^{b}$ & $107.56^{a}$ & $20.46^{f}$ & $25.32^{\mathrm{e}}$ & $32.34^{d}$ & 0.0141 \\
\hline \multicolumn{8}{|l|}{ Energy utilization } \\
\hline $\begin{array}{l}\text { Energy efficiency ratio (EER, g/ } \\
\text { Kcal) }\end{array}$ & $0.128^{b}$ & $0.134^{\mathrm{b}}$ & $0.170^{\mathrm{a}}$ & $0.24^{d}$ & $0.38^{\text {cd }}$ & $0.43^{c}$ & 0.0059 \\
\hline Energy productive value (EPV, \%) & $77.44^{b}$ & $75.32^{\mathrm{c}}$ & $94.27^{\mathrm{a}}$ & $12.86^{f}$ & $18.94^{e}$ & $22.30^{\mathrm{d}}$ & 0.0141 \\
\hline
\end{tabular}

Table 5: Effect of use fresh macro algae with or without artificial feed on feed utilization efficiency of rabbitfish (Siganus rivulatus) fry.

reported that fresh and dried gut weed can be used as a feed to substitute commercial feed for herbivorous fish such as spotted scat, (Scatophagus argus), red tilapia (Oreochromis sp.) and giant gourami (Osphronemus goramy) juveniles.

In the same trend, Siddik et al. [55] found that, the lowest final body weight and SGR were observed in treatments feeding fresh and dried gut weed as single feeds.

Moreover, herbivorous fish like tilapia generally accept plant originated ingredients better than animal originated ingredients in their diet. For example, Swain and Padhi [63] reported that tilapia grew better fed diet replacing 75\% fish meal with okra meal (a by-product of soybean meal) than fed diet containing $100 \%$ fish meal. Moreover, the rabbitfish were fed a control diet with addition of a known weight of fresh Enteromorpha placed in plastic baskets at the bottom of the rearing tanks were the higher in final body weight and SGR than fish fed at the control diet or the other treatments [56].

The results were in partial disagree with El-Tawil [64] who reported that, specific growth rate of red tilapia (Oreochromis $\mathrm{sp}$ ) improved significantly $(\mathrm{P}<0.05)$ with increasing Ulva level in the diet up to $15 \%$. Increasing Ulva level beyond $15 \%$ had no significant effects on growth. Elmorshedy [65] showed that final body weight, weight gain and specific growth rate of gray mullet Liza ramada $0.094 \mathrm{~g}$ initial body weight were increased significantly with increasing seaweeds level (Ulva sp.) up to $28 \%$ in the fish diet. And Xu et al. [51] recommend a level of less than $33 \%$ DGL in the diet for $S$. canaliculatus and the optimum level require to be investigated in future studies.

On the other hand, carnivorous fish, such as African catfish, would tend to prefer diets with animal ingredients rather than plant feedstuff, and such a conclusion is in accordance with our results showing a decrease in feed intake by fish at the levels $20 \%$ and $30 \%$ of U. lactuca in their diets was increased [66].

The highest survival rate was achieved by the T1 (fish fed at the artificial diet only) and decreased with $\mathrm{T} 2$ and $\mathrm{T} 3$ while the lowest survival rate was achieved by the T4, T5 and T6. Hence, it can be said that the total replacement or partial of artificial diet with macro algae negatively affected on survival rate of rabbitfish fry this may be due to the important role of fish meal. Whereas, fishmeal has a balanced amino acid composition [56].

But Siddik et al. [55] found that, the equal survival $(\mathrm{P}>0.05)$ of tilapia juvenile in all dietary treatments was in agreement with the study of Rahman and Meyer [67] who observed similar survival of fish fed diet with seaweed and without seaweed.

\section{Feed utilization efficiency}

As shown in Table 5 there were significant differences between the treatments in all the feed utilization parameters the highest feed intake (FI, g/fish) was achieved by T4 followed by T6, T3, T5 and $\mathrm{T} 2$ respectively. While the lowest FI achieved by $\mathrm{T} 1$. The best feed conversion ratio (FCR) was achieved with $\mathrm{T} 1, \mathrm{~T} 2$ and $\mathrm{T} 3$ followed by $\mathrm{T} 6$ and $\mathrm{T} 5$ but the T4 had the worst FCR. The highest protein efficiency ratio (EPR) and protein productive value (PPV) were achieved with the T3 Followed by T2, T1, T6, T5 and T4 respectively. In the same trend was energy efficiency ratio (EER), whereas the highest EER was obtained by T3 followed by T2, T1, T6, T5 and T4 respectively. The highest energy productive value (EPV) was obtained by T3 followed by T1, T2, T6, T5 and T4 respectively.

From these results, it can be observed that, the T3 (fish fed at the artificial diet with fresh Enteromorpha) was the highest in FCE, PER, PPV, EER and EPV. The best FCR was achieved by T3, T1 and $\mathrm{T} 2$ whereas the statistical analysis disappeared any significant difference between these the treatments. This confirmed that, the total replacement of artificial diet by fresh macro algae negatively affected on the feed utilization of rabbitfish fry while the replacement of artificial diet at $50 \%$ of feeding rate by fresh macro algae did not only negatively effect on the feed utilization of rabbitfish fry but also the replacement of artificial diet at $50 \%$ of feeding rate by fresh macro algae excelled in the feed utilization parameters compared with the use of the artificial diet only in particular the replacement of artificial diet at $50 \%$ of feeding rate by Enteromorpha.

This may be returned to macro algae improved rabbitfish fry palatable and digestible at the artificial feed as mentioned by Yone et al. [68] who interpreted the effect on growth as due to an acceleration of nutrient absorption of dietary algae. These results are in agreement with Yousif et al. [56] who found that, the fish was fed a control diet with addition of a known weight of fresh Enteromorpha placed in plastic baskets at the bottom of the rearing tanks was the best in FCR, PER and PPV than the other treatments, also they added that, Protein productive value $(\mathrm{PPV})$ affected significantly $(\mathrm{P}<0.05)$ by different levels of Ulva sp. It increased significantly with increasing Ulva level in the diet Siddik et al. [55] who found that, tilapia fed alternative1 day 
Citation: Abdel-Aziz MFA, Ragab MA (2017) Effect of Use Fresh Macro Algae (Seaweed) Ulva fasciata and Enteromorpha flaxusa With or Without Artificial Feed on Growth Performance and Feed Utilization of Rabbitfish (Siganus rivulatus) fry. J Aquac Res Development 8: 482. doi: $10.4172 / 2155-9546.1000482$

Page 6 of 8

\begin{tabular}{|c|c|c|c|c|c|c|c|c|}
\hline \multirow{3}{*}{ Items } & \multirow{3}{*}{ Start } & \multicolumn{6}{|l|}{ Treatments } & \multirow{3}{*}{ SED* } \\
\hline & & \multirow{2}{*}{\begin{tabular}{|l|} 
T1 \\
Artificial \\
Feed Only
\end{tabular}} & \multirow{2}{*}{$\begin{array}{l}\text { T2 } \\
\begin{array}{l}\text { Artificial feed } \\
\text { with Ulva }\end{array} \\
\end{array}$} & \multirow{2}{*}{$\begin{array}{l}\text { T3 } \\
\text { Artificial feed } \\
\text { with Enteromorpha }\end{array}$} & \multirow{2}{*}{$\begin{array}{l}\text { T4 } \\
\text { Ulva } \\
\text { Only }\end{array}$} & \multirow{2}{*}{\begin{tabular}{|l|} 
T5 \\
Enteromorpha \\
Only
\end{tabular}} & T6 & \\
\hline & & & & & & & $\begin{array}{l}\text { Ulva with } \\
\text { Enteromorpha }\end{array}$ & \\
\hline Moisture (M, \%) & 80.70 & $70^{c}$ & $73.83^{a b c}$ & $72.71^{\mathrm{bc}}$ & $80.43^{a}$ & $79.71^{\mathrm{ab}}$ & $80.20^{\mathrm{ab}}$ & 2.88 \\
\hline Dry matter (DM, \%) & 19.30 & $30^{\mathrm{a}}$ & $26.17^{\mathrm{abc}}$ & $27.29^{a b}$ & $19.57^{c}$ & $20.29^{\mathrm{bc}}$ & $19.80^{c}$ & 2.88 \\
\hline Crude protein (CP, \%) & 50.17 & $48.35^{\mathrm{b}}$ & $51.55^{\mathrm{ab}}$ & $48.07^{\mathrm{b}}$ & $58.63^{a}$ & $54.54^{\mathrm{ab}}$ & $56.03^{a b}$ & 3.48 \\
\hline Ether extract (EE, \%) & 9.75 & $33.84^{\mathrm{a}}$ & $27.50^{\mathrm{b}}$ & $29.48^{\mathrm{ab}}$ & $17.29^{c}$ & $17.63^{c}$ & $18.44^{c}$ & 2.27 \\
\hline Ash, $\%$ & 34.57 & $13.35^{\mathrm{b}}$ & $15.26^{b}$ & $18.04^{\mathrm{ab}}$ & $20.36^{\mathrm{ab}}$ & $18.44^{\mathrm{ab}}$ & $27.35^{\mathrm{a}}$ & 4.08 \\
\hline Gross energy (GE, Kcal/g) & 3.68 & $5.87^{a}$ & $5.45^{\mathrm{ab}}$ & $5.44^{\mathrm{ab}}$ & $4.86^{c}$ & $4.67^{c}$ & $4.84^{\mathrm{c}}$ & 0.32 \\
\hline
\end{tabular}

( $a, b$ and $c)$ Average in the same row having different superscripts significantly different at $(P \leq 0.05)$

*, SED is the standard error of difference $(\sqrt{2 \text { mean square of error/replicates })}$.

Table 6: Effect of use fresh macro algae with or without artificial feed on whole body chemical composition and energy content of rabbitfish (Siganus rivulatus) fry.

commercial feed and 1 consecutive day fresh or dried gut weed showed similar feed utilization to tilapia feed the commercial feed.

These results clearly indicated that gut weed can be used 1 day after using 1 day commercial feed without affecting feed utilization of tilapia. Also these results are partial in agreement with El-Tawil [64] reported that, supplementation of Ulva sp. to the prepared fish diet had a positive effect on FCR except fish fed the diet containing 25\% Ulva level with the poorest FCR value. As well as, Diler et al. [69] stated that PPV improved significantly with increasing dietary Ulva inclusion rate up to $15 \%$. Also, similar results were found by Elmorshedy [65] with gray mullet.

On the other hand, Abdel-Warith et al. [66] reported that, a decrease in feed intake by African catfish at the levels $20 \%$ and $30 \%$ of $U$. lactuca in their diets was improved FCR and added that, the fish fed the control diet displaying a superior PER, Protein productive values (PPV\%) values also showed a decrease when fishmeal was replaced by the U. lactuca meal source. Also, Ergün et al. [44] suggested that low-level inclusion of Ulva meal can significantly improve growth performance and nutrient utilization of tilapia fed high-lipid diets.

\section{Body chemical composition and energy content}

Whole body chemical composition and energy content of rabbitfish fry (siganus rivulatus) at the beginning and the end of the experimental period are shown in Table 6. There were significant differences between the treatments at the end of the experimental period in moisture $(M$, $\%)$, crude protein $(\mathrm{CP}, \%)$, ether extract $(\mathrm{EE}, \%)$, ash (\%) and gross energy (GE, $\mathrm{kcal} / \mathrm{g})$.

The highest moisture $(\mathrm{M}, \%)$ was achieved by $\mathrm{T} 4$ followed by $\mathrm{T} 6$, $\mathrm{T} 5, \mathrm{~T} 2$ and $\mathrm{T} 3$ but the lowest $(\mathrm{M})$ was achieved by $\mathrm{T} 1$. the highest value of (CP) was obtained by the T4 and insignificant differences between T6, T5 and T2 while the lowest value of (CP) was obtained by $\mathrm{T} 1$ and T3. The highest value of (EE) was achieved by the T1 and T3 followed by $\mathrm{T} 2$ while there are not significant differences in EE between the T6, $\mathrm{T} 5$ and T4. The highest ash was achieved with the T6 and there are not significant differences in ash between the $\mathrm{T} 5, \mathrm{~T} 4$ and $\mathrm{T} 3$ while the lowest ash was achieved $\mathrm{T} 1$ and $\mathrm{T} 2$. The highest value of GE was recorded by $\mathrm{T} 1$ followed $\mathrm{T} 2$ and $\mathrm{T} 3$ while there were insignificant differences in ash between the T4, T6 and T5.

It can be said that, an increase of EE and GE level of whole body rabbitfish fry at the end of the experimental period with the fish fed at the artificial feed or the fish fed at the artificial feed with fresh macro algae, may be due to the artificial feed contained on high level of EE $(13.78 \%)$ this resulted in increment of lipid level in body fish, this are in agreement with Siddik et al. [55] who found that, the fish which fed at the commercial feed had the highest EE followed by the fish which fed at the fresh and dried gut weed with the commercial feed while the lowest EE content was noticed with the fish were fed at fresh or dried gut weed alone.

The highest $(\mathrm{M}, \%)$ was achieved by the fish were fed at fresh macro algae but the lowest $(\mathrm{M}, \%)$ was achieved by the fish were fed at the artificial feed, this was agree with Siddik et al. [55] found that, The highest moisture content in tilapia carcass was observed in treatments fresh gut weed and dried gut weed while lowest was observed in treatments commercial feed.

While the highest ash was achieved by the fish fed at the diet without artificial feed (fresh macro algae only). This may be due to the fresh macro algae contained on high level of ash content in Ulva (20.06\%) and Enteromorpha (30.19\%) this resulted in increment of lipid level in body fish.

\section{Conclusion}

The total replacement of artificial feed with fresh macro algae had negative effect on growth performance of rabbitfish fry; however, use of the macro algae as half of the feeding rate with artificial feed had positive effect on growth performance of rabbitfish fry and reduce of the feed cost. Whereas, the T3 was the highest in the final weight $\left(\mathrm{W}_{2}\right)$ total weight gain (TG), average daily gain (ADG), relative growth rate (RGR) and specific growth rate (SGR). Followed by both the T2 and T1. Moreover, There are significant differences between the treatments in all the feed utilization parameters. The best feed conversion ratio (FCR) was achieved with T1, T2 and T3 followed by T6 and T5 but the T4 had the worst FCR.

\section{References}

1. Lam TJ (1974) Siganids: Their biology and mariculture potential. Aquacult 3 325-354.

2. Saoud IP, Mohanna C, Ghanawi J (2008) Effects of temperature on survival and growth of juvenile spinefoot rabbitfish (Siganus rivulatus). Aquacult Res 39: $491-497$

3. Woodland DJ (1990) Revision of the fish family Siganidae with descriptions of two new species and comments on distribution and biology. Indo-Pacific Fishes, No. 19 Bernice Pauahi Bishop Museum, Honolulu, Hawaii.

4. Woodland DJ (1983) Zoogeography of the Siganidae (Pisces) and interpretation of distribution and richness pattern. Bulletin of Mar Sci 33: 713-717.

5. Duray MN (1990) Biology and culture of siganids. Aquaculture Department Southeast Asian Fisheries Development Center, Tigbauan, Iloilo, Philippines.

6. Choat JH (1991) The biology of herbivorous fishes on coral reefs. The ecology of fishes on coral reefs. Academic Press, New York, USA. pp. 120-155.

7. Bariche M (2002) Biologie et Ecologie de deux especes lessepsiennes (Siganus rivulatus et Siganus luridus) Siganidae sur les cotes du Liban. These de Doctorat de l'Universite d'Aix Marseille II.

8. GAFRD (2014) Fish statistics year book. (24th edn), General Authority for Fish Resource Development, Agriculture ministry, Egypt. 
Citation: Abdel-Aziz MFA, Ragab MA (2017) Effect of Use Fresh Macro Algae (Seaweed) Ulva fasciata and Enteromorpha flaxusa With or Without Artificial Feed on Growth Performance and Feed Utilization of Rabbitfish (Siganus rivulatus) fry. J Aquac Res Development 8: 482. doi: 10.4172/2155-9546.1000482

9. Luning K (1990) Seaweeds, their environment, biogeography and ecophysiology. Willey Inter-science Publications 3: 370 .

10. Santhanam RN, Remananthan N, Jagathusan G (1990) Coastal aquaculture in India. CBS Publishers \& distributors pp.159-162.

11. Wong KH, Cheung PC (2000) Nutritional evaluation of some subtropical red and green seaweeds I. proximate composition, amino acid profiles and some physico-chemical properties. Food Chem 71: 475-482.

12. Marsham S, Scott GW, Tobin ML (2007) Comparison of nutritive chemistry of a range of temperate seaweeds. Food Chem 100: 1331-1336.

13. Fleurence J (1999) Seaweed proteins: biochemical, nutritional aspects and potential uses. Trends in Food Sci Technol 10: 25-28.

14. Satpati GG, Pal R (2011) Biochemical composition and lipid characterization of marine green alga Ulva rigida- a nutritional approach. J Algal Biomass Utln 2: $10-13$

15. Mine I, Menzel D, Okuda K (2008) Morphogenesis in giant-celled algae. Int. Review of Cell and Molecular Biol 266: 37-83.

16. Kong F, Mao Y, Cui F, Zhang X, Gao Z (2011) Morphology and molecular identification of Ulva forming green tides in Qingdao China. J Ocean China Uni 10: 73-79.

17. Wolf MA, Sciuto K, Andreoli C, Moro I (2012) Ulva (Chlorophyta, Ulvales) Biodiversity in the North Adriatic Sea (Mediterranean Italy), Cryptic species and new introductions. J Phycol 48: 1510-1521.

18. Ortiz J, Romero N, Robert P, Araya J, Lopez-Herna'ndez J, et al. (2006) Dietary fiber, amino acid, fatty acid and tocopherol contents of the edible seaweeds (Ulva lactuca) and (Durvillaea antarctica). Food Chem 99: 98-104

19. Garcia-Casal MN, Pereira AC, Leets I, Ramirez J, Quiroga ME (2007) High iron content and bioavailability in humans from four species of marine algae. J Nutr 137: 2691-2695

20. Manimala K, Rengasamy R (1993) Effect of bioactive compounds of seaweeds on the Phytopathogen (Xanthomonas oryzae). Phykos 32: 77-83.

21. Hoppe HA (1966) Nahrungsmittel aus Meeresalgen. Bot Mar 9: 18-40.

22. Tamura T (1970) Marine aquaculture, Nat Sci Foundation PB 194 OSIT, Part II, Washington, D.C.

23. Tolentino-Pablico G, Bailly N, Froese R, Elloran C (2008) Seaweeds preferred by herbivorous fishes. J Appl Phycol 20: 933-938.

24. Mullin JB, Riley JP (1955) The spectrophotometric determination of nitrate in natural waters, with particular references to see water. Analytica Chemica Acta 12: $464-480$.

25. APHA (1992) Standard methods for the examination of water and waste water. (18th edn) Amer Public Health Association, Washington DC.

26. AOAC (1984) Official Methods of Analysis. Association of Official Analytic Chemists, Inc. Arlington, Virginia, USA.

27. NRC (1993) National Research Council, Nutrient requirements of fish. National Academy Press, Washington, D.C, USA

28. Viola S, Malady S, Rappaport U (1981) Partial and complete replacement of fish meal by soybean meal in feeds for Intensive culture of carp. Aquacult 26 : 223-236.

29. SPSS (2007) Statistical package for social science (for Windows). Release 16 Copyright $\odot$, SPSS Inc., Chicago, USA.

30. Westernhagen HM, Rosenthal H (1975) Rearing and spawning siganids (Pisces: Teleostei) in a closed sea water system. Helgol Wiss Meeresunters 27: 1-18

31. Huguenin JE, Colt J (1989) Design and operating guide for aquaculture seawater systems. Dev Aquacult Fish Sci 20: 264.

32. Meade JW (1989) Aquaculture management. New Branch. York: Van Nostrand Reinhold, NY.

33. Davis J (1993) Survey of aquaculture effluents permitting and standards in the South. Southern Regional Aquaculture Centre, SRAC publications, USA.

34. Lawson TB (1995) Fundamentals of Aquacultura Engineering. New York: Chapman \& Hall, USA.

35. ANZECC (2000) (Australian and New Zealand Environment and Conservation
Council) and ARMCANZ (Agriculture and Resource Management Council of Australia and New Zealand), Australian Guidelines for Water Quality Monitoring and Reporting. National Water Quality Management Strategy Paper No. 7 , ANZECC and ARMCANZ, Canberra.

36. EPA (2003) The Environment Protection (Water Quality) Policyían overview, both the overview and a copy of the Water Quality Policy with an accompanying explanatory report are available on the EPA

37. Saoud IP, Kreydiyyeh S, Chalfoun A, Fakih M (2007) Influence of salinity on survival, growth, plasma osmolality and gill Na-K-ATPase activity in the rabbitfish (Siganus rivulatus). J Exp Mar Biol Ecol 348: 183-190.

38. Becker E (1994) Microalgae biotechnology and microbiology. Cambridge University Press, Cambridge, Great Britain.

39. Becker E (2004) Microalgae in human and animal nutrition. Handbook of microalgal culture, Blackwell, Oxford, UK.

40. Sirakov I, Velichkova K, Nikolov G (2012) The effect of algae meal (Spirulina) on the growth performance and carcass parameters of rainbow trout (Oncorhynchus mykiss). J Biol Sci Biotechnol SE/Online: pp. 151-156.

41. Norziah MH, Ching CHY (2000) Nutritional composition of edible seaweeds (Gracilaria changgi). Food Chem 68: 69-76.

42. Chapman VJ, Chapman DJ (1980) Seaweeds and their uses. Chapman and Hall, London and New York, USA.

43. Khotimchenko SV, Vaskovsky VE, Titlyanova TV (2002) Fatty acids of marine algae from the Pacific coast of north California. Botanica Mar 45: 17-22.

44. Ergün S, Soyuturk M, Guroy B, Guroy D, Merrifield D (2009) Influence of Ulva meal on growth, feed utilization, and body composition of juvenile Nile tilapia (Oreochromis niloticus) at two levels of dietary lipid. Aquacult Int 17: 355-361.

45. Güroy D, Güroy B, Merrifield DL, Ergun S, Tekinay AA, et al. (2011) Effect of dietary Ulva and Spirulina on weight loss and body composition of rainbow trout, Oncorhynchus mykiss (Walbaum), during a starvation period. J Anim Physiol \& Anim Nutr 95: 320-327.

46. Güroy B, Ergün S, Merrifield DL, Güroy D (2013) Effect of autoclaved Ulva meal on growth performance, nutrient utilization and fatty acid profile of rainbow trout (Oncorhynchus mykiss). Aquacult Int 21: 605-615.

47. Teimouri M, Amirkolaie AK, Yeganeh S (2013) Effect of Spirulina platensis meal as a feed supplement on growth performance and pigmentation of rainbow trout (Oncorhynchus mykiss). World J Fish and Mar Sci 5: 194-202.

48. Li YY, Hu CB, Zheng YJ, Xia XA, Xu WJ, et al. (2008) The effects of dietary fatty acids on liver fatty acid composition and D6-desaturase expression differ with ambient salinities in (Siganus canaliculatus). Comp Biochem Physiol 151 183-190.

49. Jackson AJ, Capper BS, Matty AJ (1982) Evaluation of some plant proteins in complete diets for tilapia (Sarotherodon mossumbicus). Aquacult 27: 97-109.

50. Ojeda FP, Muñoz AA (1999) Feeding selectivity of the herbivorous fish Scartichthys viridis: Effects on macroalgal community structure in a temperate rocky intertidal coastal zone. Mar Ecol Prog Ser 184: 219-229.

51. Xu S, Zhang L, Wu Q, Liu X, Wang S, et al. (2011) Evaluation of dried seaweed Gracilaria lemaneiformis as an ingredient in diets for teleost fish (Siganus canaliculatus). Aquacult Int 19: 1007-1018.

52. Horn M (1989) Biology of marine herbivorous fishes. Oceano Mar Biol Annu Rev 27: 167-272.

53. Fleming AE, Barneveld RJ, Hone PW (1996) The development of artificial diet for abalone. Aquacult 140: 5-53.

54. Vinoj KV, Kaladharan $P(2007)$ Amino acids in the seaweeds as an alternate source of protein for animal feed. J Mar Biol Ass Indian 49: 35-40.

55. Siddik MAB, Nahar A, Rahman MM (2014) Bossier gut weed, Enteromorpha $\mathrm{sp}$. as a partial replacement for commercial feed in Nile Tilapia (Oreochromis niloticus). Culture World J Fish Mar Sci 6: 267-274.

56. Yousif OM, Osman MF, Anwahi AR, Zarouni MA, Cherian T (2004) Growth response and carcass composition of rabbitfish (Siganus canaliculatus Park) fed diets supplemented with dehydrated seaweed (Enteromorpha sp.). Emir J Agric Sci 16: 18-26.

57. Leary DF, Lovell RT (1975) Value of fiber in production type diets for channe catfish. Trans Amer Fish Soc 104: 328-332. 
Citation: Abdel-Aziz MFA, Ragab MA (2017) Effect of Use Fresh Macro Algae (Seaweed) Ulva fasciata and Enteromorpha flaxusa With or Without Artificial Feed on Growth Performance and Feed Utilization of Rabbitfish (Siganus rivulatus) fry. J Aquac Res Development 8: 482. doi: $10.4172 / 2155-9546.1000482$

Page 8 of 8

58. Anderson J, Jackson AJ, Matty AJ, Capper BS (1984) Effects of dietary carbohydrate and fiber on tilapia (Oreochromis niloticus Linn.). Aquacult 37: 303-314

59. Von Westernhagen $\mathrm{H}$ (1973) The natural food of the rabbitfish (Siganus oramin and S. striolata). Mar Biol 22: 367-370.

60. Von Westernhagen H (1974) Food preference in cultured rabbitfishes (Siganidae). Aquacult 3: 109-117.

61. El-Sayed AM (2006) Tilapia culture. CAB International, Wallingford, UK.

62. Costa MM, Oliveira STL, Balen RE, Bueno JG, Baldan LT, et al. (2013) Brown seaweed meal to Nile Tilapia fingerlings. Arch Zootec 62: 101-109.

63. Swain PK, Padhi SB (2011) Utilization of seaweeds as fish feed in aquacult. $J$ Biol Sci 2: 35-46.

64. El-Tawil NE (2010) Effects of green seaweeds (Ulva sp.) as feed supplements in Red Tilapia (Oreochromis sp.) diet on growth performance, feed utilization and body composition. J Arabian Aquacult Soc 5: 179-193.
65. Elmorshedy I (2010) Using of algae and seaweeds in the diets of marine fish larvae. Fac Agri Saba Bacha, Alexandria University, Egypt.

66. Abdel-Warith AWA, Younis EMI, Al-Asgah NA (2015) Potential use of green macroalgae (Ulva lactuca) as a feed supplement in diets on growth performance, feed utilization and body composition of the African catfish (Clarias gariepinus) Saudi J Biol Sci 23: 404-409.

67. Rahman MM, Meyer CG (2009) Effects of food type on diel behaviours of common carp (Cyprinus carpio L.) in simulated aquaculture pond conditions. J Fish Biol 74: 2269-2278.

68. Yone Y, Furuichi M, Urano K (1986) Effects of wakame Undaria pinnatifida and Ascophyllum nodosum on absorption of dietary nutrients, and blood suga and plasma free amino- $\mathrm{N}$ levels of red sea bream. Nippon Suisan Gakkaishi 52: 1817-1819.

69. Diler IA, Tekinay A, Guroy D, Guroy BK, Soyuturk M (2007) Effects of (Ulva rigida) on the growth, feed intake and body composition of common carp (Cyprinus carpio L). J Biol Sci 7: 305-308. 